\begin{tabular}{|c|c|c|c|}
\hline & $\begin{array}{l}\text { Escola Superior } \\
\text { de Cestäoerior } \\
\text { Tecnologia } \\
\text { [ipsantarém] }\end{array}$ & 婇 & $\begin{array}{l}\text { ISSN 2029-7564 (online) } \\
\text { SOCIALINĖS TECHNOLOGIJOS } \\
\text { SOCIAL TECHNOLOGIES } \\
2014,4(1) \text {, p. } 139-150\end{array}$ \\
\hline
\end{tabular}

\title{
OVERVIEW OF FINANCIAL CONTAGION CHANNELS IN THE BANKING SECTOR OF THE BALTIC STATES
}

\author{
Laura Gudelyte \\ Mykolas Romeris University, Lithuania, l.gudelyte@mruni.eu \\ doi:10.13165/ST-14-4-1-09
}

\section{Abstract}

This article aims to determine and analyse the main features of channels of financial contagion in the banking sector of the Baltic States. The most relevant channels seem to be the risk of common lender, the channel of real estate prices, the channel of other macroeconomic shocks and the channel of volatility. This paper contributes to the further analysis of internal and external causes of financial crisis and its transmission channels in the banking sector of the Baltic States.

Purpose - to indicate and explain the main problems related to the systemic risk and the channels of financial contagion in the banking sector of the Baltic States.

Design/methodology/approach - general overview of research papers presenting concepts and methodologies of assessment of systemic risk of the banking sector, statistical analysis of financial data.

Findings - determination of the main channels and extent of financial contagion relevant to the banking sector of the Baltic States.

Research limitations/implications - the lack of information concerning the liquidity and asset structure of the banking sector of the Baltic States and the real estate prices in the Baltic States. The most common problem analysing the financial contagion and systemic risk is the lack of information (especially about the structure ofliabilities and assets of financial institutions, its maturity) and the changing new banking regulatory conditions. Due to the lack of data it is impossible to create stable and reliable statistical 
models describing the stochastic behaviour of financial contagion. We do not take into account the political factors concerning the reforms of financial market supervision that also impact financial contagion and systemic risk ant the attitude of foreign investors towards the Baltic States. The findings of this article should ground the macro-prudential policy in the small countries of supervising institutions focussing on the external factors.

Practical implications - identification of the channels of external and internal negative shocks to the banking sector of the Baltic States; useful not only for the banking executives providing business trends and officers of supervising institutions that should use not only Basel III requirements, identifying potential sources of risk in the near future, but for the rest part of the society, both ordinary citizens and entrepreneurs having current accounts and deposits in banks.

Originality/Value - modelling of systemic risk and analysis of instability causes of the banking sector by applying reliable quantitative methods in Lithuania is insufficiently developed and is impossible without knowing the mechanisms of transitions of external and internal shocks on banking sector. Researchers have provided an exhaustive analysis of contagion and channels of contagion in global extent or in another cases and regions. The banking sectors of the Baltic States are essentially controlled by the same foreign banking groups and the liquidity problems faced by international financial groups could therefore spill over into the other banks in the Baltic States. This case is not exhaustively analysed by other researchers. This paper is one of the first attempts to describe and make a quantitative assessment of the financial contagion in the Baltic States. Large dependence of the banking institutions in the Baltic States on their investors means not only the simple attraction of capital flows but additional risk that can arise due to the lack of liquidity or panics of patronising financial institutions. The findings of this article should ground macro-prudential policy focussing on the external factors.

Keywords: interbank market, systemic risk, channels of financial contagion.

Research type: literature review, general review.

\section{Introduction}

Many banking crises have occurred in conjunction with cyclical downturns or other aggregate shocks of economy and finance markets, such as interest rate increases, equity market crashes or exchange rate devaluations, and they often are transmitted from one region or country to another. Systemic risk in the Baltic States can be treated as the respective level of sensitivity of investment portfolio on internal and external factors. Increased sensitivity of individual banks to shocks due to higher leverage or greater reliance on short-term funding does not imply a higher probability that some financial institutions will default at the same time, i.e., increased systemic risk. Banking sectors of the Baltic States are similar, significantly concentrated and can be divided into several categories: large banks, medium banks and small banks.

There are many different definitions of financial contagion (see, for example, Pericoli and Sbracia, 2001). Eichengreen, Rose and Wyplosz define contagion as the 
probability that a crisis in a country at a point in time is correlated with the occurrence of a crisis in other countries, after controlling for the effects of political and economic fundamentals (for more details, see Eichengreen, Rose, Wyplosz, 1996).

In the extent of the local banking sector, financial contagion is defined as transmission of idiosyncratic shocks from one bank (or a group of banks) to other financial institutions. In this case contagion is distinguished from common shocks affecting all banks simultaneously (references). In the regional or international terms the financial contagion can be treated as transmission of financial shocks from one country to another. A common shock can be treated as the main cause of the simultaneous occurrence of a crisis across countries. In addition, financial contagion is defined as the co-movements between financial markets during the crisis after eliminating the common shock impact (see Fang and Yafeng, 2013). Forbes and Rigobon (2002) interpret financial contagion as a significant increase in cross-market linkages after a shock to a country, or a group of countries. Their paper suggests that rather than contagion existing only during the crisis period, there is strong longterm interdependence between markets. At the same time, Bekaert et al. (2005) define contagion as the excess correlation over and above what one would expect on economic fundamentals. Of course, the concept of financial contagion is developing and generalised further (for example, see Carletti, Hartmann, 2002, ECB, 2010).

To study financial stability, it is important to investigate how interdependencies across different banking systems and markets are potentially more important for financial stability than interdependencies within the system, since these links can change the behaviour of market participants (see, for example, Ghorbel, Abdelwahed, 2013). During the financial crisis the behaviour of a player active in different systems might be affected not only by a shock, but by interdependencies among the systems in which it operates. As a consequence, the same player will behave differently in each system, even if it faces no liquidity hoarding or other strategic motivation (for more details see ECB investigation, 2010).

Despite the fact that the Baltic States are a periphery area of financial markets, and the extent of the impact of the global financial crisis is moderate due to the conservative credit policy of financial institutions, there exist other channels of contagion. The systemic risk in the banking sector of the Baltic States to a large extent is a consequence of its dependence on external capital. Despite the fact that situation of Nordic banks is stable and well capitalised, this risk is increased by the fact that the majority of the Baltic banking sector is controlled by the same financial institutions operating in the Nordic countries. Financial interlinkages between financial institutions can be classified according to some types. The contagion of common lender corresponds to this type.

This article aims to determine and analyse the main features of channels of financial contagion in the banking sector of the Baltic States. Although the structure of the banking sector and its assets is quite simple and evident, there are few scientific assessments of systemic risk. At the same time, the region of the Baltic States is very sensitive to external economic shocks and this fact requires additional solutions for the assessment and management of systemic risk. 


\section{Overview of the main contagion channels in the Baltic States from one country to another}

In recent years, when viewed systemically, all banking sectors in Estonia, Latvia and Lithuania are approximately relevant. Therefore, the initial source of liquidity or solvency (default) risk from patronised financial institutions in any of the Baltic States has approximately the same impact on other banking sectors through common creditor channel. In addition, although the probability that the five patronising financial institutions from the Nordic countries representing the common creditor for the Baltic States will simultaneously withdraw their investments during the crisis period is very small, such risk still exists. In addition, there are several external transmission mechanisms.

Default risk and liquidity risk of patronising financial institutions. Modern financial institutions dependent on short-term financing via money markets face a run from short-term lenders who may decide to withdraw their funding, for example due to their own future needs of liquidity or because their own assessment of counterparty risk. Moreover, if a financial institution is still able to obtain funding of its less liquid assets, such funding causes the risk of increasing difference between the book value of the asset and the funding obtained when using it as collateral. In addition, banks may face large liquidity demands. At the same time, when an illiquid portfolio of a defaulted bank is sold on the market, the price feedback can impact on the portfolios of other financial institutions holding similar assets. This type of feedback can be treated as a shock that fragilises the capitalisation of the whole financial system. In addition, when the capital position (especially Tier-1 capital) of a bank no longer can withstand losses, it becomes insolvent, and its counterparties, with their already fragile capital positions, write off their exposures to the defaulted bank and in turn they may become insolvent, leading to a potential cascade of defaults (for more details, see Amini and Minca, 2009). Since the largest commercial banks in the Baltic States are the net debtors of foreign patronising banks and are not systemically relevant debtors in the local interbank markets, i.e. unlike in the developed interbank markets in Europe, they are not necessarily the main source of credit contagion (see Valužis and Židulina, 2010). Then again, the default risk and cascade of bank run is closely related to the concentration of the banking sector. That is evident in the Baltic States. However, the impact of increased concentration on the interbank markets stability is unclear.

Propagation of default can be modelled via domino effects using network and simulation approaches (see, for example, Gudelytè and Navickiene், 2013): a shock (which may be a liquidity shock or a loss in the value of total assets) affecting balance sheets and default of one or few institutions will propagate due to interconnectedness to neighbouring institutions and may possibly affect an important fraction of the financial system. Since the local interbank markets in separate Baltic States consist of a small number of credit institutions, it is reasonable to assume that they have direct links with each other, i.e. interbank markets in the Baltic States are complete. This means that each credit institution holds a portfolio of positions with all the remaining banks 
in the interaction-based market and that the credit institutions have the same number of partners (linkages) on the interbank market. In the current situation and during the period until now there was no counterparty risk from the side of patronising banks of the Nordic countries. In other words, the default of any patronising banks from the Nordic countries will not induce the default of patronising banks in the Baltic States despite the fact that banking sectors here are strongly concentrated with systemically relevant money supply centres.

There are also some other financial institutions residing in one of the Baltic States which also have their subsidiaries in other Baltic States. The last example of correlated defaults was the collapse of Snoras financial group.

Risk of common creditor. The systemic risk due to common lender means that some countries or regions depending on a common creditor are vulnerable to spillovers through this linkage. These spillovers result from financial interlinkages between the affected countries. The underlying presumption is that common creditor exposures in the Baltic States affected by the primary financial crisis is relatively large, implying substantial potential losses, and hence the need to restore capital asset ratios, or readjust risk exposures, accounting for the common bank lender effect. Usually spillovers through financial market interlinkages emerge from shifts in investor portfolios. The common creditor channel presupposes that financial institutions' responses to unexpected losses are fairly mechanistic (see Van Rijckeghem and Weder, 2000). Therefore, the needs of patronising financial institutions to rebalance their portfolios following losses in the primary crisis country (not necessarily in the Baltic States) leads to an instantaneous reduction of lending to other countries in which they hold exposures even if the situation in those financial markets is stable. In addition, the risk of short-term liquidity remains even if the owning financial institution should not give any more credit.

The banking sector in each of the Baltic States has one or more lending centres. These lending centres can cause cross-border spillovers in several ways (for more details, see Van Rijckeghem and Weder, 2000). Losses in one country could lead the banks to sell off assets in other countries for the sake of restoring their capital adequacy ratios. Problems in the financial system of the Baltic States can occur just due to the sudden liquidity shortage in patronising financial institutions and in the Nordic interbank markets. Therefore, the Baltic banking sector strongly depends on the monetary policy of Nordic central banks, the state of interbank markets and supervision of patronising financial institutions.

Nordic banks are major sources of financing for the banking sector of the Baltic States and also one of the most volatile ones. One of the most important channels of financial contagion is the fact that the main financial institutions in the Baltic States are owned by the same shareholders from the Nordic countries. Despite the fact that the majority of the banking sector in the Baltic States is financed by the capital of the Nordic banks and therefore they are not the source of credit risk, there is the risk of financial contagion via possible shortage of liquidity and panics of patronising financial institutions due to their point of view towards local economic policy and other problems in other countries of Central and Eastern Europe. The problem in 
patronised institutions' banking in the Baltic States can occur only due to sudden liquidity shortage in patronising financial institutions and liquidity shortage in interbank markets of the Nordic countries. Therefore, the Baltic banking sector strongly depends on the monetary policy, the situation in interbank markets, and supervision of financial institutions in the Nordic countries.

Channel of currency crisis. Another channel of financial contagion is the one of currency crises since Denmark, Norway and Sweden are outside the euro area, and the problem of sensitivity to exchange rates and its fluctuations remains. Therefore, there is a currency-based volatility and risk of sudden jumps in exchange rates, and they must be hedged in investor portfolios. The exchange rate regime is often the cornerstone of macroeconomic stabilisation programmes in emerging markets. In addition, the history of the Baltic States demonstrates that in small and open economies a fixed exchange rate target may be an effective nominal anchor to domestic prices and wages. The quest for an external anchor may turn out to be a difficult task, as shown by the collapse of several traditional fixed or crawling peg arrangements during 1990s. In particular, economists have focused on the ability of a given exchange rate regime to face potentially contagious financial crises, which seem to be an inevitable collateral inconvenience of integrated financial markets (see Habib 2002).

Investor expectations that the Lithuanian and Latvian foreign exchange rate regimes will collapse did not materialise. Of course, it would have happened in Latvia, if the IMF had not given the required volume of loans. However, the Lithuanian case demonstrated the ability to maintain adequate state of fixed exchange rate, even under pressure on the part of financial market participants. It is clear that the financial situation of banks was largely dependent on the implemented governmental policies and actions of the ECB and further emerging market participants' expectations.

Channel of sovereign debt contagion. Besides the contagious effects within the banking sector, there are the links between banking and sovereign debt that also forms an important part of systemic risk. A sovereign default may even limit the banks' capacity of originating investment to its own, initial wealth, thereby unfolding an adverse impact on the real economy. The analysis of links between banking and sovereign debt dominate recent research of systemic risk (see, for example, Manasse and Zavaloni, 2013). Bolton and Jeanne (2011) analyse the impact of government bonds as a collateral on the interbank lending market. Assuming that a fraction of banks receive an investment opportunity, sovereign risks hamper the bank's capacity to use government bonds as collateral in their balance sheets. Bolton and Jeanne (2011) and Gennaioli, Martin, and Rossi (2012) extend this analysis in the case of multiple countries. Bolton and Jeanne (2011) show that banks in each country diversify their bond holdings by creating risk diversification ex ante but risks of financial contagion ex post. At the same time, Gennaioli, Martin, and Rossi (2012) relate the strength of financial institutions to cross-country capital flows and the governmental decision to default and conclude that better financial institutions increase capital inflows to a country and reduce the government solvency risk. Conversely, Acharya, Drechsler, and Schnabl (2011) discuss the impact of banking crisis and government bailouts on the sovereign debt risk. The main insight of this research is the two-way feedback 
between the solvency of the financial sector on one hand and the public sector on the other.

In fact, the crisis in the euro area means the crisis of sovereign debt and bad fiscal policy during the previous period in PIIGS (Portugal, Ireland, Italy, Greece, and Spain) countries, but not the collapse of the currency framework itself.

Following the data on public finance, the majority of domestic sovereign debt of the Baltic States is owned by the local banking sector but the substantial part of the whole sovereign debt is owned by foreign investors. Consequently, these financial institutions have the opportunity to earn an additional return on the financial crisis due to increased risk premia. At the same time, the sovereign credit rating downgrade affects the quality of sovereign debt securities as collateral for loans in the interbank markets. Another problem that can occur in small markets relates to lack of confidence, lack of investors and the low level of liquidity in the secondary market for sovereign debt securities during the financial crisis.

Estonia has not caused any major problems with sovereign debt, so that the channel had no significant effect on the country's banking sector systemic risk. In fact, Latvia went bankrupt, and only the outer IMF assistance has enabled this country to stabilise the situation. Although a sizeable proportion of the public debt of the IMF has returned to the external creditor leveraged on favourable terms, the intervention was necessary to remedy the situation. Of course, the banking sector has experienced this effect on a huge pressure because the market during the period was dominated by government securities high risk premia. The situation of Lithuania was similar, but the Government chose to act in another way. Foreign investors had very little confidence in state facilities to repay its loans and therefore borrowed only for short time. For this reason, a significant increase in the risk premium made it difficult for local banks to finance their activities. Of course, these conditions resulted in extremely tight credit policy in the Baltic States in 2009-2011.

Impact of macroeconomic factors and the structure of the economies. There are many channels through which macroeconomic and financial linkages can arise. It is clear that deterioration of external financial conditions may affect the economy through negative impact on consumption and investment decisions, or through credit rationing, given the difficulty to identify solvent borrowers and therefore to stress the banking conditions in local markets. In addition, an economic downturn may negatively affect the valuation of financial assets, since the present value of their generated future cash flows decreases. The total impact on the economy depends not only on agent behaviour but also on the institutional framework they operate in, both of which vary across countries and over time (for more details, see Ciccarelli et al., 2013). These authors analysed the evolution and heterogeneity in macro-financial linkages and international spillovers over the last three decades for some developed economies in a unified framework. Country-specific factors remain important, and they explain the heterogeneous behaviour of agents across countries. Spillovers are found to matter in macroeconomic-financial linkages: a negative shock to a real or financial variable in a given country affects all other economies, despite the fact that the transmission is only partial. These international spillovers seem to be faster and deeper 
between financial variables than between real variables (see Ciccarelli et al., 2013). In addition, these authors showed empirically that all recessions have a common and an idiosyncratic component. In the Baltic States, international trade between the Baltic States is quite intensive, mostly based on long-term but unstable collaboration, and in general, the real-sector companies use the same financial services from the same dominating banks.

Despite the fact that the structure of economy is quite different within the Baltic States (e.g. different structure of exports), the common macro-economic trends occurring in this region (as inflation, lagged business cycles, development of real estate prices, etc.), impact the banking sectors of these countries. As in other small countries, the main part of macroeconomic channel is composed from the sensitivity of the Baltic States' economies to sudden changes of external conditions since, unlike local consumption, the export forms a very relevant fraction of GDP. In addition, many banks, even the prudent ones, cannot be protected against macroeconomic shocks better than the imprudent ones. The default models and information contagion can be applied to explain the resilience of a separate financial institution to macroeconomic shocks. As in other cases, banks in Estonia, Latvia and Lithuania are vulnerable to macroeconomic shocks and downplay the scope for contagion. For example, fluctuations of interest rates may largely impact present values of bank exposures. There is, however, the efficient allocation of interest rate risk induced by technology shocks. This paradigm was proposed by Hellwig (for more detail, see Hellwig, 1998) who showed that fraction of interest rate allocation should also be borne by early withdrawing depositors.

It is reasonable that a negative shock in one market transmits itself to the other markets, as investors adjust their portfolio allocations (see Cipriani et al., 2013). The change of interest rates, foreign financial capital flows, internal trade conditions, fiscal policy decisions and other structural factors on recent cyclical economic movements have a strong impact on the portfolio quality and balance-sheets of financial institutions.

Channel of equity market contagion. A common approach to testing for contagion is based on the analysis of correlation coefficients across asset returns. If the correlation in returns between assets in separate markets increases significantly during a crisis, this can be treated as evidence of contagion. At the same time, illiquid and shallow local equity market in the Baltic States serves as a buffer on contagion from other regions.

Channel of real estate contagion. It is evident that boom and bust cycles in real estate markets are one of the most important or even primary causes of financial crises (see Allen and Carletti, 2013). In "boom and bust times" speculators find it profitable to borrow from banks and enter the real estate market. Thus, due to the lack of macroprudential policy the result is a bubble in real estate prices in that they are higher than the discounted stream of housing services during the boom phase. Of course, it impacts the managers of patronising financial institutions and may inspire them to re-balance their portfolio of mortgage loans in other countries.

Real estate prices in virtually all of the Baltic States follow the same trend. Their importance to the quality of the loan portfolio is significant and because they can lead 
to the corresponding financial decisions of managers Then again, real estate is one of the main loan collaterals. Therefore unfavourable real estate market trends have a negative impact on the quality of credit institutions' loan portfolio.. It is proved empirically that easy credit conditions and active expansion contributed moderately to real economic growth but significantly added to overheating pressures by pushing up real estate prices, encouraging concentration of labour and capital into procyclical sectors and increasing private sector debt burden (see Ramanauskas, 2011; Hoesli and Reka, 2013).

Although mortgage lending in the Baltic countries has shrunk considerably, any price changes will have a negative impact on the Nordic banks that are the main creditors of the Baltic States' real estate and real economy sectors.

Channel of social learning and psychological factors. Social learning channel arises when agents base their decisions on noisy observations about the actions of agents in foreign markets (for more details, see Trevino, 2013). The problem of bank run due to withdrawals is solved partially by the insurance systems of deposits. However, the liabilities of the system of deposit insurance are not adequate to the extent economy and structure of the financial markets in the Baltic States. The informationbased bank run is possible because the customers in this region have "long memory" of bank crashes during the period from 1990s.

Channel of volatility contagion. Volatility contagion means the uncertainty arising from pessimistic expectations of investors as to the country risk under new global economic conditions. This external influence is generally defined as volatility contagion or volatility spillover (for more details, see Habib, 2002). While the empirical literature has investigated the volatility contagion hypothesis in stock markets, much less attention has been devoted to the propagation of interest rate and exchange rate volatility across different countries. Habib shows the impact of the volatility of external factors on financial markets by testing the hypothesis of "volatility contagion". The presence of emerging-market 'volatility contagion' might be an explanation of this result. It is complicated to measure the volatility contagion, nonetheless it means the banks' uncertainty in fixed income markets and also the impact of liquidity shortage or its expectation in near future.

Interdependence between different channels of contagion. Volatility contagion has a strong impact on the behaviour of agents and psychological factors that impact financial decisions. At the same time, several macro-economic factors also strongly impact the level of interest rates and its volatility. It is hard to measure the "total" volatility that arises from this one in fixed income markets and in stock and real estate markets. All these uncertainties together with information asymmetry can potentially encourage the panics of depositors and additional stress for the banking sector.

\section{The structure of bank assets and financial contagion risk}

The activity of the banking sector in the Baltic States is quite conservative. The most part of banking investment consists of loans. The derivatives are not popular 
and relevant in the portfolio of financial institutions of the Baltic States. However, depending on the exact structure of the interbank deposit market and the liquidation value of the bank's assets, the crisis of a single institution may spread over to other banks and become systemic.

It has been recognised that large portfolios of individual risks, such as mortgages, credit default swaps, or life insurance contracts, cannot be fully diversified due to the dependence between individual risks, which arises from exposure to common exogenous risk factors, called systematic risk, but also from contagion phenomena (see Gagliardini and Gouriéroux, 2011). At the same time, collateralised loans are quite conservative financial instruments, and the main source of risk is the credit risk resulting from individual insolvency and possibly from the change of macroeconomic conditions. Therefore, the impact of financial contagion through international channels is limited.

Classical loans dominate the structure of bank assets. In addition, the fraction of derivatives is an irrelevant part of banks assets in the Baltic States. In contrast, the provisions following financial stability information still remain at high level. At the same time, the largest part of banking activity financing is based on short-term loans and it is therefore very sensitive to the changes of interest rates and liquidity situation in money markets

Despite these facts, the main problem of the portfolios in the Baltic States consists of the limited possibilities to diversify its risks, because the local markets are shallow. At the same time, the quality of collateral is moderate.

Interbank markets. Lending between banks in the Baltic interbank markets is mainly based on collateralised loans and the remaining part of interbank lending without collateral is not systemically relevant. However, collateralised loans in interbank markets satisfy the liquidity needs for separate banks and often only reduce but not eliminate credit risk and systemic risk.

\section{Conclusions}

We explained and distinguished more strictly the notions of financial contagion and correlated defaults. We have also presented the structure of the local interbank markets as the source and channel of financial contagion through interbank linkages. In addition, we treated the risk of common creditor channel as a specific channel of financial contagion in the Baltic region not only due to the crisis in a particular country but also due to the shortage of liquidity of foreign financial institutions. The Baltic banking sector strongly depends on the monetary policy of the Nordic central banks, the state of interbank markets and the supervision of patronising financial institutions. The contagion effects of the failure of a smaller bank are limited. 


\section{References}

Acharya, V.V.; Drechsler, I.; Schnabl, P. A Phyrric Victory? - Bank Bailouts and Sovereign Credit Risk. NBER Working Paper No. 17136, 2011.

Allen, F.; Carletti, E. Systemic Risk from Real Estate and Macro-Prudential Regulation. International Jounal of Banking, Accounting and Finance, 2013, 5(1/2): 28-48.

Amini, H.; Minca, A. Mathematical Modeling of Systemic Risk.

Bekaert, G.; Ehrmann, M.; Fratzscher, M.; Mehl, A. Global Crises and Equity Market Contagion. Netspar Discussion Papers.

Bekaert, G.; Campbell R.H.; Ng, A. Market Integration and Contagion. Journal of Business, 2005, 78: 39-69.

Bolton, P.; Jeanne, O. Sovereign Default Risk and Bank Fragility in Financially Integrated Economies. CEPR Discussion Paper, 2011, No. 8358.

Broner, F. A.; R. Gelos, R. G.; Reinhart, C. M. When in Peril, Retrench: Testing the Portfolio Channel of Contagion. Journal of International Economics 2006, 69: 203-230.

Carletti, E.; Hartmann, Ph. Competition and Stability: What's Special About Banking? European Central Bank, Working Paper Series 146, May 2002.

Ciccarelli, M.; Ortega, E.; Valderrama, M. T. Heterogeneity and Cross-Country Spillovers in Macroeconomic Financial Linkages. ECB Working Paper No. 1498, 2012.

Cipriani, M.; Gardenal. G.; Guarino, A. Financial Contagion in the Laboratory: The Cross-Market Rebalancing Channel. May 2013.

Eichengreen, B.; Rose, A.; Wyplosz, Ch. Contagious Currency Crises. Scandinavian Journal of Economics, Wiley Blackwell, December, 1996, 98(4): 463-84.

Fang, J.; Yafeng, Q. Trade Link, Neighbourhood and Country Size: Which is More Important in Driving Contagion? International
Journal of Advances in Management Science 2(3), August 2013.

Fratscher, M. On Currency Crises and Contagion. Working Paper No. 139, European Central Bank, April 2002.

Forbes, K.; Rigobon, R. No Contagion, Only Interdependence: Measuring Stock Market Co-Movements. Journal of Finance, 2002, 57: 2223-2261.

Gagliardini, P.; Gouriéroux, Ch. Correlated Risks vs Contagion in Stochastic Transition Models. Série des Documents de Travail $\mathrm{n}^{\circ}$ 2012-07, Sentre de Recherche en Economie et Statistique, Journal of Economic Dynamics and Control, 2013, 37: 22412269.

Gennaioli, N.; Martin, A.; Rossi, S. Sovereign Default, Domestic Banks and Financial Institutions. Working Paper, 2012.

Ghorbel, A.; Abdelwahed, T. The Impact of Global Financial Crisis on the Dependence Structure of Equity Markets and on Risk Management. International Journal of Managerial and Financial Accounting, 2013, 5(1): 1-32.

Gudelyte, L.; Navickiené, O. Modelling of Systemic Risk of Banking Sector. Social Technologies, 2013, 3(2): 359-371.

Habib, M.M. Financial Contagion, Interest Rates and the Role of the Exchange Rate as Shock Absorber in Central and Eastern Europe. Discussion Papers No. 7 Bank of Finland Institute for Economies in Transition BOFIT 2002.

Hellwig, M. Systemische Risiken im Finanzsektor, Zeitschrift für Wirtschaftsund Sozialwissenschaften, Beiheft, 1998, 7: 1363-1389.

Hernández, L.F.; Valdes. R. O. What Drives Contagion: Trade, Neighbourhood, or Financial Links? International Review of Financial Analysis, 2001, 10: 203-218.

Hoesli, M.; Reka, K. Contagion Channels between Real Estate and Financial Markets, January 25, 2013. 
Manasse, P.; Zavaloni, L. Sovereign Contagion in Europe: Evidence from the CDS Market. January 14, 2013.

Moser, T. What Is International Financial Contagion? InternationalFinance, 2003, 6(2): 157-178.

Pericoli, M.; Sbracia, M. A Primer on Financial Contagion // Banca D'Italia Temi di Discussione, 2001, No. 407.

Podlich, N.; Wedow, M. Credit Contagion Between Financial Systems. Discussion Paper Series 2: Banking and Financial Studies No 15/2011, Deutsche Bundesbank.

Ramanauskas, T. What Caused the Recent Boom-And-Bust Cycle in Lithuania?
Evidence from a Macromodel with the Financial Sector. Working Paper series No.10, Lietuvos bankas, 2011, p. 1-51.

Recent Advances in Modelling Systemic Risk Using Network Analysis, ECB January, 2010.

Valužis, M.; Židulina, T. 2010. On the Contagion in the Baltic States. C.R.E.D.I.T. 2010 Credit Risk, Systemic Risk, and Large Portfolios. Venice, 30 September-1 October. Van Rijckeghem, C.; Weder, B. Spillovers Through Banking Centers: A Panel Data Analysis. International Monetary Fund, IMF Working Paper WP/00/88, 2000.

Trevino, I. Channels of Financial Contagion: Theory and Experiments. November 6, 2013. 